\title{
Cavernous sinus triangles - correlation between cranial and endonasal visualization
}

\author{
Gustavo Rassier Isolan ${ }^{1}$ Francisco Braga ${ }^{2}$ Ricardo Lopes de Araújo ${ }^{3}$
}

\footnotetext{
${ }^{1}$ Department of Neurosurgery, School of Medicine and Postgradution Program in Surgery at Faculdade Evangélica Mackenzie do Paraná, The Center for Advanced Neurology and Neurosurgery, Porto Alegre, Brazil

2 Department of Neurosurgery, The Center for Advanced Neurology and Neurosurgery, Porto Alegre, Brazil

${ }^{3}$ Weill Cornell University, New York City, New York, United States
}

Arq Bras Neurocir 2021;40(3):e295-e296.

Regarding the paper Microsurgical and Endoscopic Anatomy of the Cavernous Sinus (Arq Bras Neurocir 2020;39(2):83-94) published in the Brazilian Neurosurgery Journal last year, we would like to clarify that authors Gustavo Rassier Isolan, MD, Ricardo Lopes de Araújo, MD and Francisco Braga, MD, wrote this study at the time we were part of the postgraduate program in surgery at the Federal University of Rio Grande do Sul (Universidade Federal do Rio Grande do Sul - UFRGS). We want to assure that we no longer work at that university and our affiliations are following:

1. Gustavo Rassier Isolan, MD, PHD - Professor, School of Medicine and Postgradution Program in Surgery at Fac-
Address for correspondence Gustavo Rassier Isolan, MD, PhD, Faculdade Evangélica Mackenzie do Paraná e CEANN, Curitiba, Brazil (e-mail: gustavo.isolan@fempar.edu.br).

uldade Evangélica Mackenzie do Paraná. Neurosurgeon The Center for Advanced Neurology and Neurosurgery, Porto Alegre, RS, Brazil

2. Francisco Braga, MD - Neurosurgeon - The Center for Advanced Neurology and Neurosurgery, Porto Alegre, RS, Brazil

3. Ricardo Lopes de Araújo, MD - Doctoral Fellow, Weill Cornell University

Best Regards

Gustavo Isolan

Porto Alegre, March 20, 2021
DOI https://doi.org/ 10.1055/s-0041-1733996. ISSN 0103-5355.

\footnotetext{
(c) 2021. Sociedade Brasileira de Neurocirurgia. All rights reserved. This is an open access article published by Thieme under the terms of the Creative Commons Attribution-NonDerivative-NonCommercial-License, permitting copying and reproduction so long as the original work is given appropriate credit. Contents may not be used for commercial purposes, or adapted, remixed, transformed or built upon. (https://creativecommons.org/ licenses/by-nc-nd/4.0/)

Thieme Revinter Publicações Ltda., Rua do Matoso 170, Rio de Janeiro, RJ, CEP 20270-135, Brazil
} 